\title{
Reconstructing investigative journalism at emerging
}

\section{organisations}

Maria Konow-Lund

While academic research has mainly focused on how legacy media organisations conduct their general news production work, fewer studies have focused on specialised practices such as investigative journalism in relation to innovation and technology. Scholars, however, have observed that news production is increasingly taking place outside the newsroom. In this context, the present article explores the ways in which emerging media organisations innovate and adapt practices of watchdog journalism within their staffs and facilities. Its case studies include a co-op that seeks to engage ordinary citizens in production; a collaborative data desk that aims to professionalise a variety of actors, including local journalists, citizen journalists, activists, hackers, developers and media organisers; and a global tech company that seeks to produce investigative journalism with national but also global resonance.
Keywords

investigative journalism, organisation, innovation, technology, values, start-ups, emerging organisations

\section{INTRODUCTION}

Recent studies have indicated that the 'lone wolf' era of investigative journalism is coming to an end, as watchdog journalism is reconstructed across borders with a special focus on collaboration, digital technology and networking (Berglez \& Gearing, 2019; Konow-Lund, Gearing, \& Berglez, 2019; Sambrook, 2018; Lewis, 2018; Alfter, 2019). In just the past two decades, we have seen an increase in journalistic innovation involving users (Harhoff \& Lakhani, 2016), while fewer studies have focused on how traditional and emerging forms of investigative journalism seek to involve participants and users in watchdog journalism aiming to hold power to account. Few researchers, for example, have addressed the ways in which emerging media organisations aiming to conduct investigative journalism are developing and adjusting their practice as a cross-institutional endeavour. Little value remains, it would seem, in the "consensual (self-) presentation of journalism-in terms of its occupational ideology, its professional culture, and its sedimentation in routines and organisational structures (cf. the newsroom) -in the context of its reconfiguration as a post-industrial, entrepreneurial, and atypical way of working and of being at work" (Deuze \& Witschge, 2018, p. 165). Some scholars have even predicted the end of the newsroom (Wahl-Jorgensen, 2009). Still, the viability of the legacy news desk persists across institutions (Anderson, 2013) and borders (Alfter \& Candea, 2019). This article builds upon Anderson's observation that news production is moving from news desks to news ecosystems (2013, p. 168) by examining some of the characteristics and qualities of that ecosystem in the contexts of its most 
progressive players-the new organisations that are currently driving watchdog journalism. The present article addresses the research gap concerning the reconstruction of investigative journalism that has accompanied the emergence of new organisations and actors in the field by asking how they are implementing new technologies, practices and organisational values. It does so by exploring how these groups organise their work and constantly readjust their practice according to developing technological affordances. Three emerging media organisations interested in investigative journalism were chosen as cases: (1) a co-op aiming for a generally participatory approach to holding power to account; (2) a collaborative local-national Google-funded data desk desk aiming to generate participation from groups of citizens, activists, local journalists, students, bloggers and so on; and (3) a global tech company aiming to cultivate digital participation from its users. All the cases were based in the United Kingdom but are representative of start-ups and emerging organisations, including tech companies, around the world

INVESTIGATIVE JOURNALISM AND CHANGING CONDITIONS FOR ORGANISATIONS

Investigative journalism is hard to define; some scholars associate it with an art form (Stetka \& Örnebring, 2013), while others devote whole essays to its finer points of scope and practice (van Eijk, 2004). The American tradition of investigative journalism, which focuses on professional skills and the practitioner's ability to share experiences and practices with other colleagues (Houston, 2009), has held sway over much recent cross-border collaborative work within investigative journalism, such as the collaborative work on the tax haven leaks known as the Panama Papers (2016) and Paradise Papers (2017). Consequently, in this article, investigative journalism will be understood as a practice which brings with it shareable skills (Houston, 2009; Aucoin, 2005). While Larsen (2016) laments the lack of consensus around a working definition of investigative journalism, the network journalism model (Henrich, 2011; Beckett \& Mansell, 2008) of the American investigative journalism tradition (Konow-Lund et al., 2019) is in the ascendant, particularly following the launch of the nearly 400-journalist global collaborative Panama Papers investigation.

The recent Cairncross Review report attributes the rise of the network journalism model to the fact that "the news publishing business is undergoing an extraordinary period of contraction in both main traditional sources of revenue: advertising and circulation" (Cairncross, 2019, p. 7)1. It also notes the importance of emerging platforms and their contribution to in-depth reporting. According to the report, two aspects of public-service newsgathering practice are particularly hurt by these declining revenues. First, there is investigative journalism, particularly that which is concerned with "abuses of power in both the public and private spheres" (Cairncross, 2019, p.17). This journalism is both 'high cost', in terms of staff commitment, and 'high risk', in terms of the possibility of failure. Second, there is the work of daily beat reporting at various public institutions, especially at the local level, including local councils, because this scope of journalism lacks the perceived relevance of regional, national or global investigations (Cairncross, 2019).

While the concept of investigative journalism remains ill-defined, the practice is thriving and, importantly, evolving, in the words of Hamilton (2016). Researcher James Aucoin (2005) evokes philosopher Alasdair MacIntyre to describe social practice as "sustained and, indeed, [it] progresses through the efforts of practitioners to meet and extend the practice's standards of excellence" (p. 5). Investigative journalism is not readily framed as such (Protress et al. 1991; Stetka \& Örnebring, 2013). Still, Investigative Reporters and Editors (IRE), the organisation which has had most impact on how investigative reporting has evolved in America since the 1960s, characterises the practice of investigative journalism as "the reporting, through one's own initiative and work 
product, of matters of importance to readers, viewers or listeners. In many cases, the subjects of the reporting wish the matters under scrutiny to remain undisclosed" (Investigative Reporters and Editors, Inc. 2019). This article understands investigative journalism in line with how it is used by IRE-that is, as a practice. Established in 1976, IRE has consistently associated investigative reporting specifically with practices, experiences and skills which can be shared and disseminated through, for example, boot camps and conferences (Aucoin, 2005; Kaplan, 2013). In line with a seminal report by David Kaplan (2013), executive director of the Global Investigative Journalist Conference (GIJC), this article positions digital technology at the centre of changes in the practice of investigative reporting. Another recent book on nonprofit centres and journalism by Magda Konieczna (2018) also emphasises the impact of technological and social networking upon the resources and funding available to horizontal investigative journalism (see also Heft, Alfter, \& Pfetsch, 2017). There is more and more interdisciplinary collaboration within journalism (for an overview, see Lewis \& Usher, 2013; Olsen, 2018; Baack, 2018; Gynnild, 2013; Lewis \& Westlund, 2015), and researchers must begin to assess the new and restructured practices now driving the field, just as researchers once did for legacy media organisations during times of great change (see Tuch- man, 1978; Schlesinger, 1978; Gans, 2004[1979]). In addition, legacy traditions and practices continue to inform contemporary changes.

Storsul and Krumsvik (2013) frame media innovation as the implementation of ideas and theoretical models either in a market or a social setting. By revisiting existing knowledge, they suggest newsrooms can reconstruct norms, routines, devices, and so on for their different needs. They identify five media-related innovations: (1) product innovation, which relates to how media products are innovated; (2) process innovation, which concerns how either media products or processes are produced and distributed; (3) position innovation, which looks at how a media company implements strategic alterations to change its brand or image; (4) paradigmatic innovation, which refers to a change in the mindset, values or business models of an organisation; and (5) social innovation, which implies changes "that meet social need or improve people's lives" (Storsul \& Krumsvik, 2013, p. 16-17). This article draws in particular upon process innovation as the means through which emerging organisations produce investigative journalism, but it also draws upon paradigmatic innovation, in the sense that today's news workers are compelled to revisit legacy mindsets, values and business models. The focus on these aspects of media-related innovations is chosen as a consequence of asking how investigative journal- ism is being reconstructed in terms of both changing technologies, new practices and values.

TECHNOLOGICAL AFFORDANCES AND VALUES

Affordance is here understood to be a property of both an actor and the environment. While looking at the ways in which journalism shifted from traditional newspapers to online news sites, Boczkowski (2004, 2001) used the term 'affordance' to highlight the "potential complementary relations between an organism and its environment ... indicat(ing) how the world could be acted on by the organism" (van Leeuwen, Smitsman, \& van Leeuwen, 1994, p. 176, as cited in Boczkowski, 2001, p. 19). Originally, James J. Gibson used the concept to emphasise the quality of an environment which allows an individual to accomplish an action.

For Gibson, the affordances of objects or the environment were understood to comprise their potential: "the surface of clay is only clay, but it may be molded in the shape of a cow or scratched or painted with the profile of a cow or incised with the cuneiform characters that stand for a cow ... it is more than just a surface of clay" (1979, p. 42). Norman (1988) used the notion to describe human-machine interactionto him, affordance referred to the capacity of a thing as understood by a person: "There already exists the start of a psychology of materials and of things, the 
study of affordances of objects. When used in this sense, the term affordance refers to the perceived and actual properties of the thing" (p. 9).

The notion of affordance can clarify the relations between actors in emerging organisations and technological platforms or tools which are either available for use or already implemented. One such example of a technological affordance is the ability for investigative journalists to draw on collaborative online software. In a recent article, Bunce, Wright and Scott (2018) use the collaborative online software technology Slack as a case study to explore the ways in which digital technology is now intertwined with the organisation of journalistic practice and the creation of virtual newsrooms, and entire virtual news cultures, with all of their opportunities and challenges. An awareness of how technology is being shaped socially (Singer, 2004; Domingo, 2006) is particularly useful for the development of a strategy to exploit technological affordances to greatest effect. Christensen and Overdorf (2000) note that organisations have core capabilities deriving from their resources, processes and values ('the standards by which employees set priorities'). These kinds of organisational capabilities propel decisions for the practice of investigative journalism as well.

While researchers have long argued that news- room workers tend towards a deterministic view of technology (Örnebring, 2016, 2010, 2009), times have changed, and new affordances (and a new appreciation of existing affordances) may be impacting the field, leading to, among other things, new forms of interdisciplinary collaboration. Here, collaboration is understood to mean a shared effort towards a common end (Konow-Lund et al., 2019). Astrid Gynnild (2013) emphasises the porous boundaries between various interdisciplinary actors in journalism, such as reporters and programmers. Gynnild, like Charles Lewis (2018), the entrepreneur and innovator of a number of organisations within investigative journalism, emphasises the new mindset among "news professionals" (Gynnild, 2013, p. 727) and notes that innovation tends to feed on itself. Hence innovation, whether it is technology or process related, leads to more innovation, and collaborative online software allows this dynamic to emerge in very disparate locations. She further points out that the exploitation of technological possibilities in journalism both challenges traditional journalism and enables the development of new ideas and behaviours. When looking at the values of emerging organisations, the concept of affordance enables us to question the actors' awareness of their decision-making with regard to technology and thus to avoid a deterministic perspec- tive (Örnebring, 2010).

This article explores three main aspects of the reconstruction of investigative journalism as a developing situation, arguing that a scarcity of resources forces organisations to draw on cross-institutional collaboration as a tool, and that technology is vital to the contemporary era's modes of collaboration. The article's theoretical approach also takes into account how organisational values are negotiated as new practices are adopted.

\section{METHODOLOGY}

The present article uses three case studies, all chosen for the ways in which they challenge the notion of the newsroom. The journalistic co-op Bristol Cable, the local-national data desk Bureau Local and the tech company BuzzFeed all developed very untraditional perspectives on the newsroom and respond well to the research gap around emerging organisations and the implementation of new practices of investigative journalism (Moe \& Syversten, 2007). The co-op Bristol Cable is owned by its two thousand members and produces a quarterly newspaper while creating events that involve citizens in agenda-setting and news decision-making. Bureau Local is a Google- and philanthropically-funded platform based in London which is part of the non-profit Bureau for Investiga- 
tive Journalism. BuzzFeed is privately owned and, according to Lucy Küng (2015), has received $\$ 96.3$ million in funding from thirteen different investors. I interviewed twenty-three informants in all for this project: six at Bristol Cable, ten at Bureau Local (including some collaborators in the main newsroom at the Bureau of Investigative Journalism), and seven at the Guardian, both at the data desk and in the general newsroom. The interviewees filled as many different roles as possible, given the concentrated scope of the organisations in question. I conducted about three weeks of field observation at Bristol Cable and four weeks at Bureau Local, completing semi-structured qualitative interviews mostly at the end of the stay in each newsroom. I did not conduct field observation at BuzzFeed in London. Just as I planned to join the newsroom, about one hundred journalists were laid off; out of respect for the informants, I complied with their wish to do interviews instead. Twenty-three interviews were transcribed and categorised manually by topics, concepts and patterns.

Aiming to draw upon the methodologies of the classic news ethnographies (Tuchman, 1978; Schlesinger, 1978; Gans, 1979) as well as trying to uncover specific patterns in newsroom practices, I planned to stay close to journalists to observe not only how they talked about their work but also how they executed tasks, communicated among themselves, shared their work, and interacted, both in person and online. I quickly experienced a number of challenges. First of all, the informants I had approached over the past three years were all very slow to respond, but I followed up with them by sending new emails, then finally calling, which met with responses, however reluctant. One exception was the Bureau for Investigative Journalism, whose managing editor swiftly responded to my request for access and invited me to talk about my project. I chose to start with the smaller newsrooms, then go on to the larger newsrooms, all during the spring and summer of 2018.

During my observation, I found that the journalists mostly sat at their desks with headphones on, and some of the newsrooms placed me at a desk so far from the journalists I wanted to shadow that it was difficult to even see anything. I concluded that this was due to the journalists' lack of time and capacity for my questions. I decided that I needed a new strategy, so I began to carefully observe communications, roles and interactions, especially during staff meetings-times when the way things actually worked became much more obvious and 'real'. I used these observations to inform my lengthy semi-structured interviews, which could last up to ninety minutes. In addition, I tried to interview as many informants as I could, hoping to situate the changing routines of certain individuals in the larger context of the whole newsroom, which was the level of discourse and order of operations most relevant to my interests. I offered everyone anonymity; interestingly, some of my informants asked me to add their names to their quotes. In all, then, this article is based upon eight weeks of field observation at the aforementioned two newsrooms, plus the semi-structured qualitative interviews.

1. BRISTOL CABLE: THE EMERGENCE OF PARTICIPATORY INVESTIGATIVE JOURNALISM

Bristol Cable is a non-professional citizen journalists' co-op which provides tools and training to members of its community to empower them to investigate and report news stories via digital technology (The Bristol Cable, 2019). The idea for this journalistic co-op, which is owned by the citizens themselves, arose from a collaboration among three college students (Saelens, interview December 22, 2017) who wanted to redefine public-service journalism. The co-op charges its members three pounds per month.1 My Bristol Cable informants talked in particular about local information gaps (also called 'black holes'; see Howells, 2015) which were emerging in Britain as a casualty of a journalistic monopoly there, whereby five companies controlled more than 80 percent of the market, and 43 percent of localities had but a single source of local news (Harris, 2016). The founders of Bristol Cable noted that local media was under great strain 
around the country, and some publications were closing down (interview, Bristol Cable, January 26, 2018). Bristol Cable's aim was to start up a media organisation which could hold local power to account by inspiring real citizens to participate in this effort. While Bristol Cable understood the value and impact of digital platforms, they also emphasised face-toface engagement with their members.

On the first day of my field observation, for example, my main contact wanted to explain the ideas behind Bristol Cable, so we walked around the block and then around Bristol itself. He described the coop's engagement with the city and its people by pointing out the past, present and future of the area:

The reason why I thought it would be great to take you on a walk the first time is because, as a media organisation which wants to do things differently, we don't want to just be deskbound journalists. We don't just sit behind our computers doing research that doesn't really mean much to peoples' lives. It's very much a case of being rooted in, or having an understanding, at least, of the plurality of communities which exist here in Bristol-the kind of make-up of day-to-day lives for all of the people across the city. (Media coordinator, Bristol Cable, 2017)

The walk demonstrated Bristol Cable’s presence on location, above and beyond the kinds of interaction which have become so prevalent online. This was discussed in several Wednesday meetings which centred upon the values and norms of Bristol Cable (field observation, Bristol Cable, November, 2017). The issue was not only reflected upon but also acted upon, during, for example, an event on November 13, 2017 in a deprived area in Knowles West. There, Bristol Cable met with co-op members and gave them newspapers to hand out, then went door-to-door to meet other people, some of whom were eager to talk to the media coordinators about what was important to them. The event enabled any engaged citizen or participating co-op member to participate in the work of Bristol Cable by sharing their own stories, critiquing recent work by the co-op, or offering other feedback. The Bristol Cable media coordinators emphasised the importance of targeting deprived areas in particular, arguing that the most relevant news stories could be found there, if one were proactive and knew where to look:

What I was able to glean from doing that was that it wasn't just an opportunity to invite people to a Cable event that was organised in that area, but it was very much a case of hearing what people had to say. And that informed the article I've written for the next print edition, which looks at this particularly deprived area.
(Media coordinator, 2017)

In tandem with Bristol Cable's emphasis on place, its founders also confronted many quandaries about developing digital technology. At one weekly meeting, visual impact online, via video clips, design, illustrations and so on, was discussed in detail, as was social media (field observation, Bristol Cable, November 15, 2017). During the event, a freelance writer described how he worked journalistically while addressing the topic of drugs and prison. The writer and Bristol Cable staff then encouraged the co-op member to propose story ideas in relation to this topic, encouraging group participation in the ongoing investigative initiative. It was vital for Bristol Cable that this took place physically as an event.

My field observations, discussions and interviews made it clear that Bristol Cable staff found technology to be necessary but felt that it must accommodate, not alienate, the audience. Despite scarce resources at the co-op, its founders would continuously seek out creative ways to not only develop and implement technological tools but also make them more accessible:

Even De Correspondent, which says it's about developing a relationship with your readers, and they can feed back knowledge to you, it's a comment section and an 
email list-it's really limited-which is kind of why it's intimidating for us to be, like, let's try and develop this thing. We've got a great developer who's, like, I want to do it, I really want to do it, which is why I want us to hire him, he's ex-Guardian and he's built our membership system, the back end. He's really keen to do that, and we don't know what it will look like yet, but it just doesn't exist. (Media coordinator, Bristol Cable, 2017)².

At Bristol Cable, then, practitioners balanced their time behind the computer with their time away from it. The priority was not the widest reach possible but instead the ability to reach the people who needed to be reached, even by knocking on doors or otherwise demonstrating Bristol Cable's commitment to its community. The primary aim of this emerging organisation was to collaborate with the community and in this manner make an impact through its journalism and its engagement with society.

To summarise, this subchapter on Bristol Cable has introduced a co-op which primarily aimed to involve citizens as collaborators and participators and in this sense introduce a social change of sorts into its journalistic practice. Digital technology (and virtual communication) was important to Bristol Cable, but equally important was the ability to accommodate onsite dialogue. More importantly, this case revealed the ways in which organisational values were adjust- ed along the way.

2. THE BUREAU LOCAL: CREATING LOCAL AND NATIONAL COLLABORATIVE INVESTIGATIVE JOURNALISM

The Bureau Local also aimed to address the journalistic 'black holes' which followed the decline of local newspapers, and especially the drop-off in the ability of local media outlets to cover big issues or undertake vital investigations to hold those in power to account (see informal internal document from Cairncross Review) ${ }^{3}$. The managing editor was particularly interested in creating a hub of some sort to stimulate collaboration among a variety of professional journalists and other new actors through which it would be easy for them to share information and help each other on both collaborative and individual stories. She then applied for Google News Initiative ${ }^{4}$ money for a technological media hub and persuaded the data editor at the Sunday Times to lead the project. Through this initiative, Bureau Local began to develop a new media ecology which would enable its journalists to initiate collaborations across organisations as well. The managing editor wanted to transfer the collaboration model which ICIJ had tested internationally to local, regional and national arenas, though she knew there would be challenges:
Collaboration is really, really hard. One of the things that I was really concerned about when I was scoping out and developing the plan for Bureau Local, which is all about collaboration, was would it work? Journalists are under siege as resources are being cut so much, and in such an environment, ironically the last thing that they're going to want to do is share, because they need to preserve every single story for themselves. Actually, the opposite has been true. It hasn't been that difficult at all; it's been amazing (Managing editor, Bureau Local 2018).

Bureau Local administrators installed the software platform Slack to allow participants to create an account and log into a system through which they could communicate with each other, as well as with the administrators. In addition to the managing editor, the journalists at Bureau Local included a senior reporter, an award-winning local reporter, a data journalist/developer and a community organiser, and they explored other technological tools as well to enhance their collaboration with local reporters, developers, bloggers, activists and media actors in their area. According to my informants, data mining would propel (and change) entire investigations, via what was already in the 1970 s known as 'precision journalism' (Gynnild, 2013). 
[In the past] you might have gotten one documentyou wouldn't have gotten a cache of documents, for example. So, there is a vast amount of new resources and information that has become available to reporters that wasn't available in the past. The Panama Papers and the Paradise Papers-you couldn't have done that in the past, because you just would not have been able to get that amount of information, nor have had the means to dig into such a huge amount of information. The ICIJ has been going for twenty-five years, and they've always worked around data stories, but their data has been much smaller in the past (Managing editor, Bureau Local, 2018).

In other words, the Bureau Local sought to transfer the success and global impact of the Panama Papers investigation to the national and local levels of watchdog journalism via what the managing editor referred to as an interdisciplinary collaboration among journalists, bloggers, activists, students and anybody else who wanted to hold power to account. Technological affordances facilitated collaboration across various communities and environments:

We believe that the ability to scrutinise power should be accessible to everyone. We're aiming to empower more people to engage with and therefore be informed by investigative reporting. In the age of the internet, the way people access local information can take many formsit can be through a local paper, TV, radio station, blog, community forum, etc. (Director Megan Lucero, Bureau Local, April 26, 2018).

When Director Megan Lucero started working at Bureau Local, one of her earliest investigations was inspired by her work at The Times and The Sunday Times on political data analysis for the 2015 general election and the 2016 EU referendum. Her team was the only one in the media industry to reject polling data ahead of the elections (Bureau of Investigative Journalism, n.d.). This meant that Lucero and her team did not use polling data in their analysis work, as they did not find it robust enough. Basically, this meant that Megan Lucero and her team created their own digital analytical tool rather than trust a tool that other organisations used (Ceecon, 2019). It also meant that The Times was one of the very few newspapers that did not run incorrect seat predictions. Instead, the team drew upon other data sources ${ }^{5}$, sources they believed were more trustworthy than the most used source in order to produce powerful, accurate analyses. Lucero brought the same data approach to her work at the Bureau Local during the general election of Theresa May in 2017 and once again demonstrated how an independent approach to data sources, including polling data, could lead to innovative ways of approaching accurate storytelling. Lucero emphasises the importance of activating digital technology in tandem with the values of either the individual journalist or the broader newsroom culture. This applies to not only the digital tools used in investigations but also internal communications platforms:

People signed up as members. And as we spoke to local reporters and local people, many said that there was little opportunity for things to change. That Theresa May would win a huge majority and that there was no other reality. We were very interested in this notion and wondered, why is it that people didn't feel their vote had the power to change politics? So, our question for the investigation started with: Who does have the power?

(Director Megan Lucero, Bureau Local, April 26, 2018)

Early and often, Bureau Local staff held meetings to clarify notions and concepts such as 'data journalism', which was potentially intimidating or alienating to some participants in the organisation. In general, all the Bureau Local stakeholders prioritised digital skills and pooled their knowledge to shape their new watchdog roles and help others contribute to the cause. Several journalists even emphasised the importance of teaching themselves new skills, such as how to use a spreadsheet, in order to compete with 
senior journalists who may not have digital skills. Ultimately, the Bureau Local succeeded in fostering collaboration among local press workers to have a national impact.

While Bristol Cable was founded by activists who sought social change through innovative dialogue with citizens in their local community, the Bureau Local linked the same ideals to a more traditional professional product made available to anyone who was interested in participating in it. In short, the Bureau Local aimed to link professional local journalists and their organisations with each other, and to teach anyone who wanted to participate in professional data journalism. An excellent journalistic product was the intended result for the Bureau Local.

\section{BUZZFEED: THE INNOVATION OF VIRAL DIGITAL MUCKRAKERS}

Among the newly established platforms used as cases for this article, BuzzFeed struggled the most to gain credibility as a source of investigative journalism. For one thing, the platform began by featuring mostly animal videos, listicles ${ }^{6}$ and quizzes. It was a mixed blessing:

People are like oh and back then if you say you're from BuzzFeed, it's, I'm sorry, what is that? I think that is unfortunate some of the time. Other times it's actually quite nice. People underestimate you. So, they start talking to you when maybe if they knew you were from the big serious New York Times, they would say, whoa, I can't talk to you, but oh, I'm from Buzzfeed, and they start talking (Reporter, BuzzFeed, April, 2018)7.

The investigative journalists at BuzzFeed were generally young (ages twenty-five to thirty-three; interview, reporter, April 12, 2018) and filled a rather small team devoted to a form of journalism inspired by American practice (interview, reporter, Buzfeed, April, 2018). To them, it was essential to get to the truth, to hold power to account, and to get the correct facts. At the same time, the journalists could not stress enough that in-depth stories with a lot of facts did not need to be boring. Investigative journalism at BuzzFeed did not necessarily privilege collaboration across the organisation-its journalists, whose technical skills included some facility as both developers and online reporters, were encouraged to focus entirely on the story, and to tell it with maximum emotional impact. If users could connect to the story, staffers felt, they would finish reading it, no matter how long it was (reporter, Buzfeed, April, 2018). In this sense users are looked upon more as an active or interactive audience than actual users. This suggestion is much in line with a development found by
Ahva and Heikkilä (2016, p. 316), where they suggest that the term users gives the wrong association and that scholars prefer the term audience. Consequently, it is worth asking when implementing new digital technology, who defines the relationship between users, participators or audiences. In the BuzzFeed case, for example, users are defined as a commercial audience where the aim is to engage them with professional journalism.

Working as an investigative journalist at BuzzFeed meant allocating time for in-depth research in a traditional journalistic manner but also being present at places where sources would be and letting the stories suggest themselves (see, for example, Ettema \& Glasser, 1998; extensive interviews with American investigative journalists). Traditional investigative journalism depends on one's ability to locate and network with unique and exclusive sources (see, for example, Sambrook, 2018; de Burgh, 2008). By locating exclusive sources to which few other journalists had access, BuzzFeed journalists were able to generate unique stories. They were also careful to consider digital distribution and collaboration from the very start. Another distinct characteristic with BuzzFeed is how the process of production and the final product are intertwined; there is a strong link between the emotions prompted by a story and the possibility that it could go viral. While the initial journalistic 
insight might be traditional in nature, the journalistic skill and craft to make it connect emotionally with the audience on social media platforms are necessarily innovative: "You spend a few months in this environment, and you, kind of by osmosis, begin to understand what are the sorts of things that are seen to be successful here-what works and what doesn't" (interview, journalist, BuzzFeed, April 12, 2018). This reporter then elaborated on how testing and experimentation are part of the BuzzFeed production process.

And we also just relentlessly test everything at Buzzfeed, so at quite a basic level, we'll always $\mathrm{AB}$ test different headlines against each other. So, we'll run an optimiser and we'll write for every story, say, six different headlines, and then the optimiser will tell you this was the most popular, and it'll automatically switch the headlines [according to] whichever one was most popular with the readers (Interview, reporter, BuzzFeed, April $12,2018)$

An optimiser digitally shapes and amplifies potential headlines; my informants explained how, for example, six thousand people will see one of six different headlines, and the system will determine how many clicks each headline gets and promote the headline that people are most likely to click on.
One informant found this to be really interesting, "because it just tells you in the subtle framing of the headline what people are more likely to click and less likely to click, and what's the most likely to engage them and least likely to engage" (interview, reporter, BuzzFeed, April 12, 2018). Testing and experimentation concerning what the audience would prefer implies that the in-depth reports presented by BuzzFeed seek global 'users' who might better be understood, in fact, as an audience. In other words, in order to offer engaging content, BuzzFeed resorts to very traditional investigative journalism but adapts it to a different (and digital) platform.

BuzzFeed does the same thing for its images, and the office tracks statistics on a story's digital success as well. Journalists can see, for example, exactly where users stop reading a story or how many people drop off. BuzzFeed's use of social media replaces, to a degree, the beat reporting of old: "With a very big story, occasionally you overhear someone talking in the pub about it and that's always really exciting but it's very rare that it happens. Whereas with Buzzfeed you publish something and because everything is just distributed socially, the minute you publish, your whole newsfeed just lights up with people talking about your story and reacting to the story and you get notified of all of that" (interview, reporter, BuzzFeed, April, 2018). If a user tweets a story that a BuzzFeed reporter has written, the story will automatically add the reporter's Twitter handle to it, so anytime any user shares a story from BuzzFeed's website, the relevant reporter will be notified: "It just means that you can see the chitchat that's happening about that story and you can see people saying this part of the story's really shocking or criticising parts of it" (BuzzFeed reporter, April, 2018). Hence, this immediate feedback allows the reporter to adjust the story, for example, by altering its presentation or deploying additional technology to emphasise certain aspects. Immediate and systematised feedback also allows the media organisation to manage or remove those stories which do not achieve measurable engagement from the audience.

Few studies have explored BuzzFeed-led investigations as a specific case, even though BuzzFeed as a media platform is eager to legitimise its journalistic products by following in the footsteps of legacy media (Stringer, 2018). Some researchers emphasise that BuzzFeed has always cultivated digital experimentation aimed at a viral impact, but investigative journalism remains the gold standard for the organisation. This standard is often met through traditional methods, such as meeting with sources on location, far from the digital newsroom: "The team we work with is very traditional in terms of getting out of the office, and I think that is one of the best things about 
some of the old media organisations" (reporter, April 16,2018 ). While there might be a huge capacity within the staff for promoting a story on social media and otherwise capitalising upon the possibilities of the internet, the journalistic craft at BuzzFeed is still reminiscent of traditional investigative work

\section{CONCLUSION}

This article has considered the ways in which investigative journalism is being rebuilt at certain emerging media organisations, using traditional journalistic practices in new and often digital-first contexts.

While they are structured differently, these three British organisations are all emerging in their own ways and negotiating new means of producing indepth journalism. The differences among them relate to technology, innovation and the negotiation of newsroom values, as well as to their respective understandings of the audience's role. Bristol Cable, a co-op, originally aimed to involve citizens directly in the production of journalism and even investigations. In subsequent years, my informants admitted that their work demanded professional oversight to some degree. For the Bureau Local, users could become producers but only by absorbing professional standards in the interests of an excellent final result which was impactful both locally and nationally. Finally, BuzzFeed, a global tech company which took on journalistic production, aimed to engage its audience but not involve them in production. Innovation in the practice of investigative journalism at BuzzFeed has primarily been about the format, whereas the content has depended on traditional investigative journalism. BuzzFeed seeks to commercialise complex topics and reach younger generations with its stories by pooling resources and collaborating across organisations.

\section{Maria Konow-Lund}

Associate Professor, Oslo Metropolitaan University

Maria.Konow-Lund@oslomet.no

\section{ACKNOWLEDGEMENT}

This project has received funding from the European Union's Horizon 2020 research and innovation programme under the Marie Skłodowska-Curie Grant Agreement No. 746899

\section{NOTES}

1. Bristol Cable allows members (as of 2019) to contribute either three, five or ten pounds per month, or whatever amount the individual member prefers.

2. The informant wanted to add the following statement to his quote: 'This was my understanding of De Correspondent's offering at the time, but I've not experienced it as a reader, so the actual experience may be different. What I was getting at is this industry leader for engagement in news with an innovative platform actually seemed to have a pretty basic set-up in terms of tech. I think the engagement ethos of their correspondents is likely a major aspect of their offer. But I still think the ways of opening up engagement with audiences in the internet age are full of as yet unknown and unbuilt possibilities. And that's still the question: What can we build to change the way audiences relate to and contribute to news? Increasingly, we've realised the tech approach to this is such a big undertaking that, while there are some things we can experiment with, sustainable innovation and infrastructure will need to be built collaboratively' (Informant, Bristol Cable, May 6, 2019)

3 . This is an internal note which argues why the Bureau of Investigative Journalism believes investigative journalism within nonprofit companies should be given charitable status. See Department for Digital Culture, Media and Sport, 2018

4. See Google, 2018.

5. Lucero and her team drew upon a statistical technique referred to as a 'Classification Tree', originally used by the New York Times to predict the primaries in 2008. (for more details, see Ceccon, 2015).

6. A listicle follows a thematic structure of topical points but includes enough content to appear as an article.

7. When reading this quote about a year later, the informant asked for the following to be added: "The more time that passes, the more that BuzzFeed is considered a regular part of the journalistic firmament, and therefore we are underestimated less often." (Informant, Buzzfeed in email, 7 May 2019). 


\section{REFERENCES}

Ahva, L., \& Heikkilä, H. (2016). Mass, audience, and the public. In T. Witschge, C. W. Anderson, D. Domingo, \& A. Hermida (Eds.), The SAGE handbook of digital journalism (pp. 315-325). London: SAGE.

Alfter, B. (2019). Cross-border collaborative journalism A step-by-step guide. London: Routledge.

Alfter, B., \& Candea, S. (2019). Introduction to crossborder collaborative journalism: New practice, new questions. Journal of Applied Journalism and Media Studies, 8(2), 141-149.

Anderson, C. W. (2013). Rebuilding the news: Metropolitan journalism in the digital age. Philadelphia, PA: Temple University Press.

Aucoin, J. (2005). The evolution of American investigative journalism. Columbia, MO: University of Missouri Press.

Baack, S. (2018). Practically engaged. Digital Journalism, 6(6), 673-692. https://doi.org/10.1080/21670811.201 7.1375382

Beckett, C., \& Mansell, R. (2008), Crossing boundaries: New media and networked journalism. Communication, Culture and Critique, 1, 92-104.

Berglez, P., \& Gearing, A. (2018). The Panama and Paradise Papers: The rise of a global fourth estate. International Journal of Communication, 12, 4573-4592.
Boczkowski, P. J. (2001). Affording flexibility: Transforming information practices in online newspapers (Unpublished doctoral dissertation). Cornell University, Ithaca, NY.

Boczkowski, P. J. (2004). Digitizing the news: Innovation in online newspapers. Cambridge, MA: MIT Press.

The Bristol Cable (2019). About. Retrieved from https:// thebristolcable.org/about/

Bunce, M., Wright, K., \& Scott, M. (2018). "Our newsroom in the cloud": Slack, virtual newsrooms and journalistic practice. New Media and Society, 20(9), 3381-3399.

Cairncross, F. (2019). The Cairncross review: A sustainable future for journalism Policy paper, Department for Digital, Culture, Media and Sport. London: DCMS. Retrieved from https://www.gov.uk/government/publications/the-cairncross-review-a-sustainable-futurefor-journalism

Ceccon, S. (2015). The election explained by the Times Data Team. Digital Times. Recieved October 23, from https://medium.com/digital-times/the-electionexplained-by-the-times-data-team-482d3ab95f5c\#. no3g1tdp1

Christensen, C. M., \& Overdorf, M. (2000). Meeting the challenge of disruptive change. Harvard Business Review, March-April. Retrieved from https://hbr. org/2000/03/meeting-the-challenge-of-disruptivechange
De Burgh, H. (2008). Investigative journalism (2nd ed.). London: Routledge.

Department for Digital, Culture, Media \& Sport (2018). Call for evidence on sustainable high-quality journalism in the UK. UK Government. Retrieved from https://www.gov.uk/government/consultations/callfor-evidence-on-sustainable-high-quality-journalismin-the-uk

Deuze, M., \& Witschge, T. (2018). Beyond journalism: Theorizing the transformation of journalism. Journalism, 19(2), 165-181.

Domingo, D. (2006). Inventing online journalism: Development of the internet as a news medium in four Catalan newsrooms (Doctoral dissertation). Universitat Autònoma de Barcelona, Barcelona. Retrieved from http://hdl.handle.net/10803/4190

Ettema, J. S., \& Glasser, T. L. (1998). Custodians of conscience: Investigative journalism and public virtue. New York, NY: Colombia University Press.

Gans, H. J. (2004 [1979]). Deciding what's news: A study of CBS Evening News, NBC Nightly News, Newsweek and Time (25th anniversary ed.). Evanston, IL: Medill School of Journalism, in association with Northwestern University Press.

Gibson, James J. (1979). The ecological approach to visual perception. Boston, MA: Houghton Mifflin. 
Google. (2018). Google News Initiative. Retrieved from https://newsinitiative.withgoogle.com/

Hamilton, J. T. (2016). Democracy's detectives: The economics of investigative journalism. Cambridge, MA: Harvard University Press

Harhoff, D., \& Lakhani K. R. (Eds.). (2016). Revolutionizing innovation: Users, communities, and open innovation. Cambridge, MA: MIT Press.

Harris, J. (2016, January). Bristol Cable founders: 'We are holding people to account for their actions'. The Guardian. Retrieved from https://www.theguardian. com/media/2016/jan/24/bristol-cable-newspaperpublic-interest-journalism

Heft, A., Alfter, B., \& Pfetsch, B. (2017). Transnational journalism networks as drivers of Europeanisation. Journalism, 18(5), 1183-1202.

Heinrich, A. (2012). What is "network journalism”? Media International Australia, 144(1), 60-67.

Howells, R. (2015). Journey to the centre of a news black hole: Examining the democratic deficit in a town with no newspaper (Unpublished doctoral dissertation). Cardiff University, Cardiff.

Investigative Reporters and Editors, Inc. (2019). IRE Awards FAQ. Retrieved November 30, 2019, from https://www.ire.org/awards/ire-awards/faq
Kaplan, D. E. (2013). Global investigative journalism: Strategies for support (A report to the Center for International Media Assistance) (2nd ed.). Washington, DC: Center for International Media Assistance, with the National Endowment for Democracy.

Konieczna, M. (2018). Journalism without profit: Making news when the market falls. Oxford: Oxford University Press.

Konow-Lund, M., Gearing, A., \& Berglez, P. (2019). Transnational cooperation in journalism. In Oxford Encyclopedia (June, 2019). Retrieved from https:// oxfordre.com/communication/view/10.1093/ acrefore/9780190228613.001.0001/acrefore9780190228613-e-881

Küng, L. (2015). Innovators in digital news. London: I. B. Tauris.

Larsen, A. G. (2017). Investigative reporting in the networked media environment. Journalism Practice, 11(10), 1231-1245

Lewis, C. (2018). Tear down these walls: Innovations in collaborative accountability research and reporting. In R. Sambrook (Ed.), Global teamwork: The rise of collaboration in investigative journalism (pp. 5-25) Oxford: Reuters Institute for the Study of Journalism, University of Oxford.

Lewis, S. C., \& Usher, N. (2014). Code, collaboration, and the future of journalism. Digital Journalism, 2(3), 383-393.
Lewis, S. C., \& Westlund, O. (2015). Actors, actants, audiences, and activities in cross-media news work. Digital Journalism, 3(1), 19-37.

Moe, H., \& Syvertsen, T. (2007). Media institutions as a research field: Three phases of Norwegian broadcasting research. Nordicom Review, Jubilee issue, 149-167.

Norman, D. A. (1988). The psychology of everyday things. New York: Basic Books.

Olsen, G. R. (2017). A new platform for quality journalism? A study of four U.S. nonprofit university centers and their attempt to save professional reporting through using classrooms as newsrooms (Unpublished doctoral dissertation). University of Bergen, Bergen.

Örnebring, H. (2009). The two professionalisms of journalism: Journalism and the changing context of work. Oxford: Reuters Institute for the Study of Journalism, University of Oxford.

Örnebring, H. (2010). Technology and journalism-as-labour: Historical perspectives. Journalism, 11(1), 57-74.

Örnebring, H. (2016). Newsworkers: A comparative European perspective. London: Bloomsbury.

Protess, D.L., Cook, F.L., Doppelt, J.D., Ettema, J.S., Gordon, M.T., Leff, D.R., \& Miller, P. (1991). The journalism of outrage: Investigative reporting and agenda building in America. New York: Guilford 
Sambrook, R. (Ed.). (2018). Global teamwork: The rise of collaboration in investigative journalism. Oxford: Reuters Institute for the Study of Journalism, University of Oxford.

Schlesinger, P. (1978). Putting "reality" together: BBC News. London: Methuen.

Singer, J. B. (2004). Strange bedfellows? The diffusion of convergence in four news organisations. Journalism Studies, 5(1), 3-18.

Stetka, V., \& Örnebring, H. (2013). Investigative journalism in Central and Eastern Europe: Autonomy, business models, and democratic roles. International Journal of Press/Politics, 18(4), 413-435.

Storsul, T., \& Krumsvik, A. H. (2013). What is media innovation? In T. Storsul, \& A. H. Krumsvik (Eds.). Media innovations. A multidisciplinary study of change (pp. 13-26). Gothenburg: Nordicom.

Stringer, P. D. (2018). An examination of two digital native news organisations, BuzzFeed and Vice (Unpublished doctoral dissertation). University of Leeds, Leeds.

Tuchman, G. (1973). Making news by doing work: Routinizing the unexpected. American Journal of Sociology, 79(1), 110-131.

Tuchman, G. (1978). Making news: A study in the construction of reality. New York: The Free Press.

van Eijk, D. (2005). Investigative journalism in Europe. Amsterdam: Vereninging van Oderzoeksjournalisten. van Leeuwen, L., Smitsman, A., \& van Leeuwen, C. (1994). Affordances, perceptual complexity, and the development of tool use. Journal of Experimental Psychology: Human Perception and Performance, 20(1), 174-191. 